\title{
Blood lead level and correlation with pregnancy-associated anaemia
}

Jehan Hamadneh ${ }^{1}$, Adnan Massadeh², Shereen Hamadneh ${ }^{3}$, Manal Kassab4, Nahla S. Al-bayyari Yousef Khader ${ }^{6}$, and Wafa Sbuihat ${ }^{7}$

1. Department of Obstetrics and Gynecology, Faculty of Medicine, Jordan University of Science and

Technology, Irbid, Jordan

2. Department of Medicinal Chemistry and Pharmacognosy, Faculty of Pharmacy, Jordan University of

Science and Technology, Irbid, Jordan

3. Department of Maternal \& Child Health, Faculty of Nursing, Al-albayt University, Mafraq, Jordan

4. Department of Maternal \& Child Health, Faculty of Nursing, Jordan University of Science and Technology, Jordan

5. Department of Nutrition and Food Technology, Al-Huson University College, Al-Balqa Applied

University, Al-Salt, Jordan

6. Department of Community Medicine, Public Health and Family Medicine, Faculty of Medicine, Jordan

University of Science and Technology, Jordan University of Science and Technology, Irbid, Jordan

7. Department of Applied Biological Sciences, Faculty of Paramedical Science, Jordan University of Science and Technology, Irbid, Jordan

\section{RESEARCH}

Please cite this paper as: Hamadneh J, Massadeh A, Hamadneh S, Kassab M, Al-bayyari N, Khader Y, Sbuihat W. Blood lead level and correlation with pregnancy associated anaemia. AMJ 2018;11(4):219-226.

https://doi.org/10.21767/AMJ.2018.3375

\section{Corresponding Author:}

Jehan M. Hamadneh

Department of Obstetrics and Gynecology

Faculty of Medicine, Jordan University of Science and Technology, Irbid, P.O Box: 3030, Jordan.

Tel: +962-799166694

Email: jehan_Hamadneh@yahoo.com; Jmhamadneh@just.edu.jo

\section{ABSTRACT}

\section{Background}

The most common reason that leads to anaemia is related to the reduction in certain trace elements such as Fe. However, it has been found that an elevation in some other heavy metals such as $\mathrm{Pb}$ could also lead to anaemia.

\section{Aims}

This research aims to assess the Correlation between $\mathrm{Pb}$ blood levels and Fe, Haemoglobin levels during pregnancy among Jordanian women.

\section{Methods}

A cross-sectional study was conducted in the Northern area of Jordan. Venous blood samples collected from 167 pregnant women for the determination of haemoglobin (Hb), Fe and Pb levels of which 17 in the first trimester, 19 in second trimesters, 131 in third trimesters. Women were classified into two groups, the first group included cases with blood $\mathrm{Pb}$ Levels $\geq 10 \mu \mathrm{g} / \mathrm{dL}$ (high blood $\mathrm{Pb}$ level group, $\mathrm{n}=118$ ) and the second with blood Lead levels less than $10 \mu \mathrm{g} / \mathrm{dL}$ (low blood Lead level group, $\mathrm{n}=49$ ).

\section{Results}

About 71.4 per cent of women had anaemia ( $n=120$; $\mathrm{Hb}<10.5 \mathrm{~g} / \mathrm{dl}$ ) and 70.7 per cent of women had a high blood $\mathrm{Pb}$ level of $\geq 10 \mu \mathrm{g} / \mathrm{dL}$ ). $\mathrm{Pb}$ blood levels ranged from 6.45 to $28.0 \mu \mathrm{g} / \mathrm{dL}$. The mean (SD) of blood Pb level was 12.1 (4.1) $\mu \mathrm{g} / \mathrm{dL}$. The mean haemoglobin and Fe levels did not differ significantly between women with low and high levels of $\mathrm{Pb}$. Blood $\mathrm{Pb}$ levels were not significantly correlated with haemoglobin levels ( $r=-0.025 ; P=0.747)$ nor with iron levels $(r=0.099 ; P=0.241)$. After adjusting for important variables, $\mathrm{Pb}$ was not significantly associated with haemoglobin $(P=0.223)$ and with iron $(P=0.116)$.

\section{Conclusion}

The level of $\mathrm{Pb}$ in the blood of pregnant women has no any association with haemoglobin and Fe levels during pregnancy. 


\section{Key Words}

Lead, haemoglobin, iron

\section{What this study adds:}

\section{What is known about this subject?}

Studies show that Fe doesn't necessarily associate with a change in $\mathrm{Pb}$ blood levels among older female children or adolescents.

\section{What new information is offered in this study?}

Study findings show that $\mathrm{Pb}$ blood levels are higher among women with income less than $600 \mathrm{JD}$, women in the third trimester, and among women who were using multivitamins.

3. What are the implications for research, policy, or practice?

The level of $\mathrm{Pb}$ in the blood of pregnant women has no any association with haemoglobin and $\mathrm{Fe}$ levels during pregnancy. Further studies are needed to elucidate this relationship.

\section{Background}

Iron deficiency anaemia is the most common cause of anaemia in pregnancy ${ }^{1}$ the prevalence of Fe-deficiency anaemia is around 46-66 per cent in developing countries. ${ }^{2}$ The most common reason that leads to anaemia is related to the reduction in certain trace elements such as Fe. However, it has been found that an elevation in some other heavy metals such as $\mathrm{Pb}$ could also lead to anaemia. ${ }^{3-7}$

Human exposure to $\mathrm{Pb}$ occurs through diet, air, drinking water where $\mathrm{Pb}$ pipes are being used, ingestion of $\mathrm{Pb}$ products, ${ }^{4}$ and exposure to old leaded paint chips or pigments of lead-glazed pottery which is known as PICA in pregnancy. $^{8}$

A previous study reported that blood $\mathrm{Pb}$ levels $\geq 10 \mu \mathrm{g} / \mathrm{dL}$ is significantly correlated with anaemia, decreasing $\mathrm{Fe}$ absorption and negatively affecting hematologic indices. ${ }^{3,9-}$

11 The explained mechanism of lead-induced anaemia is related to the fact that by increasing $\mathrm{Pb}$ level in the blood, the Heme-formation, which is essential Fe metabolic step, will be interfered and this, in turn, will increase the rate of red blood cell destruction and blocking iron absorption. ${ }^{12}$ Moreover, it was reported that insufficient Fe might amplify $\mathrm{Pb}$ contamination by increasing retention and absorption of $\mathrm{Pb}$ in the body, ${ }^{9}$ which in turn affects an important $\mathrm{Fe}$ dependent metabolic step in Heme-biosynthesis. ${ }^{12}$
The presence of $\mathrm{Pb}$ prevents the formation of haemoglobin which causes $\mathrm{Pb}$-induced anaemia (hypochromic microcytic anaemia). ${ }^{9}$ Hypochromic microcytic anaemia can result from a significant reduction in Fe level even if no $\mathrm{Pb}$ is present, but the presence of $\mathrm{Pb}$ causes deterioration of anaemia.

Severe anaemia, typically less than seven can be associated with significant maternal and foetal complications. ${ }^{11}$ Anaemia during pregnancy has negative health impact on both maternal and foetus outcomes, such as premature delivery, ${ }^{2}$ and intrauterine growth retardation. ${ }^{2}$ According to WHO, the lower limits of normal haemoglobin level are $12 \mathrm{~g} / \mathrm{dL}$ in women and $14 \mathrm{~g} / \mathrm{dL}$ in men and normal haemoglobin level up to $11 \mathrm{~g} / \mathrm{dL}$ percent in pregnancy. ${ }^{8}$ So any haemoglobin concentration less than $11 \mathrm{~g} / \mathrm{dL}$ during pregnancy by WHO standards should be considered anaemia. In developing countries pregnant women with $\mathrm{Hb}$ level $<10.5 \mathrm{~g} / \mathrm{dL}$ still tolerate pregnancy, labour and delivery without negative outcomes, so pregnant women with $(\mathrm{Hb}<10.5 \mathrm{~g} / \mathrm{dL})$ was assumed anaemic. ${ }^{8}$

The difficulty in establishing a precise diagnosis of leadinduced anaemia status of pregnant women represents a complicating factor in the understanding of the relationship between maternal Fe level and trace elements level such as lead blood levels. This study aimed to determine the correlation of blood $\mathrm{Pb}$ levels with $\mathrm{Fe}$ levels and haemoglobin levels during pregnancy among Jordanian women.

\section{Method}

A cross-sectional study was conducted to determine the correlation of blood lead levels with iron levels and haemoglobin levels during pregnancy in a group of pregnant women attending a teaching hospital in the north of Jordan. Women were randomly selected from the patients' care records irrespective of the trimester of the pregnancy. All included pregnant women were non-alcoholic and no PICA cases. Women with any disease that may affect $\mathrm{Pb}$ blood levels (gestational hypertension, gestational diabetes and those who receive blood transfusion) were not included in the study. A total number of 167 pregnant women met the inclusion criteria and were included in this study.

Data were collected using a questionnaire. The first part of the questionnaire included the socio-demographic and relevant characteristics of the participants such as age, education, income, parity, trimester of pregnancy, daily intake of Fe and multivitamins. 
A trained researcher collected an aliquot of $3 \mathrm{mls}$ of venous blood samples from pregnant women during their visits to the maternal clinics. Blood was transferred into EDTA tube immediately centrifuged ( $4500 \mathrm{RCF}$ for $10 \mathrm{~min}$ ) to separate the plasma from whole blood to prevent the transfer of $\mathrm{Pb}$ from erythrocytes. $\mathrm{Pb}$ in blood was measured by taking $0.5 \mathrm{~g}$ of Ammonium Di-hydrogen Phosphate $\left(\mathrm{NH}_{4} \mathrm{H}_{2} \mathrm{PO}_{4}\right)$ which was mixed with $2 \mathrm{mls}$ Triton $\mathrm{X} 100$ in a $100 \mathrm{~mL}$ glass bottle at the room temperature. Graphite Furnace Atomic Absorption Spectrometry (GFAAS) (also known as Electrothermal Atomic Absorption Spectroscopy (ETAAS) was used to determine the concentration of $\mathrm{Pb}$ at wavelengths of $283.3 \mathrm{~nm}$. GFAAS is a type of spectrometry that uses a graphite-coated furnace to vaporize the sample. Briefly, the technique is based on the fact that free atoms will absorb light at frequencies or wavelengths characteristic of the element of interest (hence the name atomic absorption spectrometry).

The digestion of samples was done by mixing of $0.1 \mathrm{~mL}$ of a mixture with $0.05 \mathrm{~mL}$ of sample, whereas to determine $\mathrm{Fe}$ concentrations samples were diluted 1:3 with deionized water. Flame Atomic Absorption Spectrometer (FAAS) was used to determine the concentration of Fe at wavelengths of $248.3 \mathrm{~nm}$ with a slit width of $0.5 \mathrm{~nm}$. Both Flame and Graphite manufactured by Unicam Atomic Absorption, United Kingdom, model (SOLAAR M5).

Pregnant women were divided into two groups using the CDC cut off point of $10 \mu \mathrm{g} / \mathrm{d}^{11,12,13}$ High blood $\mathrm{Pb}$ Levels $\geq 10 \mu \mathrm{g} / \mathrm{dL}(\mathrm{n}=118)$ and 2 ) low Pb levels $<10 \mu \mathrm{g} / \mathrm{dL}(\mathrm{n}=49)$.

Data were analysed using the Statistical Package for Social Sciences (SPSS) version 20. Pearson correlation was used to correlate between blood $\mathrm{Pb}$ level, Fe, and Haemoglobin. The differences between means were analyzed using independent t-test. Multiple Linear Regression analysis was used to analyse the association between $\mathrm{Pb}$ (independent variable) and other dependent variables including Haemoglobin and Fe. For statistical analysis, a $p$-value of $<0.05$ was considered statistically significant.

\section{Results}

Blood samples were taken from 167 pregnant women (17 (10.2 per cent) in the first trimester, 19 (11.4 per cent) in second trimesters, and 131 (78.4 per cent) in third trimesters). A total of 92 (55.8 per cent) women aged less than 30 years and 93 (57.8 per cent) had a bachelor degree or higher degrees (Table 1). About 71.4 per cent of women had anaemia $(n=120 ; \mathrm{Hb}<10.5 \mathrm{~g} / \mathrm{dl})$, and 70.7 per cent of women had a high blood $\mathrm{Pb}$ level of $\geq 10 \mu \mathrm{g} / \mathrm{dL}$. Pb blood levels ranged from 6.45 to $28.0 \mu \mathrm{g} / \mathrm{dL}$. The (mean $\pm \mathrm{SD}$ ) of blood $\mathrm{Pb}$ level was 12.1 (4.1) $\mu \mathrm{g} / \mathrm{dL}$.

Table 2 shows the mean $( \pm \mathrm{SD}$ ) of haemoglobin, $\mathrm{Pb}$, and $\mathrm{Fe}$ levels and the analysis of the differences according to the studied characteristics using independent t-test. The mean of blood Pb level differed significantly according to income, trimester, and multivitamin use, being higher among women with income less than $600 \mathrm{JD}$, women in the third trimester, and among women who were using multivitamins. The mean of blood Haemoglobin level differed significantly according to income, trimester, and multivitamin use, being higher among women with income less than $600 \mathrm{JD}$, and women in the first trimester (Table 2).

Table 3 shows the means of haemoglobin and iron among women with low and high levels of $\mathrm{Pb}$. Using the independent test, the mean haemoglobin and Fe levels did not differ significantly between women with low and high levels of $\mathrm{Pb}$. Blood $\mathrm{Pb}$ levels were not significantly correlated with haemoglobin levels $(r=-0.025 ; P=0.747)$ nor with Fe levels ( $r=0.099 ; P=0.241)$.

Table 4 shows the multiple linear regression of the association between $\mathrm{Pb}$ and other parameters including haemoglobin, and Fe. After adjusting for important variables, $\mathrm{Pb}$ was not significantly associated with Haemoglobin ( $P=0.223)$ and with Fe $(P=0.116)$. Haemoglobin level was correlated significantly with gestational age $(P<0.005)$ (Table 4).

\section{Discussion}

$\mathrm{Pb}$ exposure remains a public health problem among childbearing age women and their developing foetus. High $\mathrm{Pb}$ level during pregnancy can adversely affect maternal, and foetus health. ${ }^{12,14}$ Previous $\mathrm{Pb}$ exposures during other life stages will be stored, and then bone $\mathrm{Pb}$ stores are mobilized during periods of pregnancy and breastfeeding stage. ${ }^{15,16}$ This, in turn, can result in lasting adverse health effects on both the mothers and their infants. ${ }^{15,16}$

This study aimed to determine the correlation of blood lead levels with iron levels and haemoglobin levels during pregnancy among a sample of Jordanian women. Study findings show that $\mathrm{Pb}$ blood levels are higher among women with income less than $600 \mathrm{JD}$, women in the third trimester, and among women who were using multivitamins. The association between high $\mathrm{Pb}$ blood levels among lowincomes mothers could be related to the fact that lowincome pregnant women could hardly maintain a healthy lifestyle that includes regular physical activity and having 
the adequate nutrition that increases heavy-metal excretion. ${ }^{17-20}$ The reason for increasing the level of $\mathrm{Pb}$ during third trimester is related to the fact that $\mathrm{Pb}$ stored in the skeleton released and mobilized during pregnancy especially the third trimester. Another study finding supports this finding. ${ }^{21}$ Pregnant women on multivitamins show a high $\mathrm{Pb}$ concentration because vitamins supplementation is one of many other materials that are containing $\mathrm{Pb}{ }^{22}$

Although $\mathrm{Pb}$ was found to be high in most of the pregnant women in the current study, haemoglobin level doesn't correlate with blood $\mathrm{Pb}$ levels. Our finding is consistent with other studies. ${ }^{23,24}$ However, findings show that there is a decrease in haemoglobin content with increasing blood $\mathrm{Pb}$ levels. ${ }^{25-28}$ These differences in the results could be related to the difference in sample size and in blood lead levels recorded in these studies. Also, the differences in age of other study participants' which included children could cause the differences in results.

The noticeably high blood $\mathrm{Pb}$ levels which were present in the participants of the current study could be due to high contamination from environmental pollution and the past lead exposure that may be mobilized during pregnancy from endogenous bone $\mathrm{Pb}$ stores that result in elevation in maternal blood levels. It has been reported that during pregnancy the increased blood $\mathrm{Pb}$ is either related to endogenous (bone saved), bone $\mathrm{Pb}$ stores are mobilized during periods of pregnancy, or from previous lead pollution. $^{33}$

Anaemia is a health problem among pregnant women, which is associated with a decrease in some trace elements as Fe and an increase in heavy metals as lead. Concerning Fe levels in pregnant women and its relation with blood $\mathrm{Pb}$ level, our findings using Pearson correlation, showed no significant correlation between $\mathrm{Pb}$ levels and Fe levels $(r=0.099, P=0.241)$. This indicates that $\mathrm{Fe}$ does not necessarily associate with a change in $\mathrm{Pb}$ blood levels as some previous studies reported. ${ }^{8 ; 29,31-33}$

Our study finding is similar to many other findings that found no association between Fe deficiency and increased blood $\mathrm{Pb}$ concentrations. ${ }^{34-37}$ However, a study conducted on young children showed an association between Fe levels and blood $\mathrm{Pb}$ levels after taking iron supplementation. ${ }^{35-39}$ Furthermore, an association between Fe supplementation and blood $\mathrm{Pb}$ levels in infants with very low blood lead concentrations have been observed. ${ }^{40}$ It is possible that the difference in study findings is related to differences in the age distribution of the study subjects, the assumptions used, or the degrees of $\mathrm{Pb}$ exposure. Studies show that $\mathrm{Fe}$ doesn't necessarily associate with a change in $\mathrm{Pb}$ blood levels among older female children or adolescents. ${ }^{38,40}$

However, and similar conclusion to our findings was reached among adolescent women owing to the overshadowing effects of oestrogen on Pb levels. ${ }^{34,37}$ Also, it has been concluded that pregnant women have lower blood $\mathrm{Pb}$ concentrations than men and there is no association between high blood $\mathrm{Pb}$ levels and $\mathrm{Fe}$ deficiency as oestrogen promotes bone mineralization and redistributes blood $\mathrm{Pb}$ into bone in women. ${ }^{35,38}$

\section{Conclusion}

Previous research findings showed an inverse correlation between blood $\mathrm{Pb}$ levels with $\mathrm{Fe}$ and haemoglobin levels during pregnancy. However, our finding showed that the level of $\mathrm{Pb}$ in the blood of pregnant women has no any association with haemoglobin and $\mathrm{Fe}$ levels during pregnancy. This finding is inconsistent with other research results which showed that blood $\mathrm{Pb}$ level is negatively affected the haematological parameters which may eventually lead to Fe deficiency anaemia during pregnancy. In conclusion, blood Fe level can be well correlated with haemoglobin concentration. The decrease in blood Fe level leads to the decrease in haemoglobin concentration. However, haemoglobin and Fe levels did not differ significantly between women with low and high levels of $\mathrm{Pb}$ which indicates that the level of $\mathrm{Pb}$ in the blood of pregnant women has no any association with haemoglobin and $\mathrm{Fe}$ levels. Further studies are needed to elucidate this relationship.

\section{References}

1. Ahmad N, Kalakoti P, Bano R et al. The prevalence of anaemia and associated factors in pregnant women in a rural Indian community. Australasian Medical J. 2010;3(5):276-280.

2. WHO guideline: Calcium supplementation in pregnant women. Geneva, World Health Organization, 2012.

3. Scholl T. Maternal iron Status: Relation to fetal growth, length of gestation and the neonate's iron endowment. Nutr Rev. 2011;69(Suppl 1):S23-S29.

4. Hegazy AA, Zaher MM, Abd El-hafez MA, et al. Relation between anemia and blood levels of lead, copper, zinc and iron among children. BMC Research Notes. 2010;3:133-141.

5. European Food Safety Authority (EFSA) Panel on Contaminants in the Food Chain (CONTAM). Scientific Opinion on Lead in Food. EFSA J. 2010;8:1570-1577. 
6. Soylak MS, Sarac M, Mendil D. Determination of trace metals in mushroom samples from Kayseri, Turkey. Food Chemistry. 2005;92:649-452.

7. Volesky B, Holan ZR. Biosorption of heavy metals. Biotechnol. Prog. 1995;11(30):235-250.

8. Alomary A, Al-Momani IF, Massadeh AM. Lead and cadmium in human teeth from Jordan by atomic absorption spectrometry: Some factors influencing their concentration. Science of the Total Environment. 2006;369:69-75.

9. Gulson B, Mizon K, Korsch M, et al. Low Blood Lead Levels Do Not Appear to Be Further Reduced by Dietary Supplements. Environ Health Perspect. 2006;114(8):1186-1192.

10. Centers for Disease Control Prevention (CDC). (2007). CDC's Advisory Committee on Childhood Lead Poisoning Prevention Interpreting and managing blood lead levels $<10$ microg/dL in children and reducing childhood exposures to lead: recommendations of CDC's Advisory Committee on Childhood Lead Poisoning Prevention. MMWR Recomm. 56:1-16.

11. Melku M, Addis Z, Alem M, et al. Prevalence and Predictors of Maternal Anemia during Pregnancy in Gondar, Northwest Ethiopia: An Institutional Based Cross-Sectional Study Anemia. 2014;2014:108-593.

12. Wells EM, Navas-Acien A, Herbstman JB, et al. Low-level lead exposure and elevations in blood pressure during pregnancy. Environ Health Perspect. 2011;119(5):664669.

13. Shah F, Kazi TG, Afridi HI, et al. Temperature controlled ionic liquid-dispersive liquid phase microextraction for determination of trace lead level in blood samples prior to analysis by flame atomic absorption spectrometry with multivariate optimization. Microchemical J. 2012;101(14):5-10.

14. Ettinger AS. Wengrovitz AG. Guidelines for the identification and management of lead exposure in pregnant and lactating women. U.S. Department of Health and Human Services Atlanta, GA. 2010.

15. Grandjean P, Bellinger D, Bergman A, et al. The faroes statement: Human health effects of developmental exposure to chemicals in our environment. Basic Clin Pharmacol Toxicol. 2008;102:73-5.

16. Bellinger DC, Teratogen update: Lead and pregnancy. Birth Defects Res A Clin Mol Teratol. 2005;73(6):409-20.

17. Anderson K, Nisenblat V, Norman R. Lifestyle factors in people seeking infertility treatment - A review. Aust N Z J Obstet Gynaecol. 2010;50(1):8-20.

18. Genuis SJ, Birkholz D, Rodushkin I, et al. Blood, urine, and sweat (BUS) study: monitoring and elimination of bioaccumulated toxic elements. Arch Environ Contam Toxicol. 2011;61(2):344-57.

19. Sears ME, Kerr KJ, Bray RI Z. Arsenic, cadmium, lead, and mercury in sweat: a systematic review. J Environ Public Health. 2012:184745.

20. Hertz-Picciotto I, Schramm M, Watt-Morse $M$, et al. Patterns and determinants of blood lead during pregnancy. Am J Epidemiol. 2010;152(9):829-837.

21. Klitzman S, Sharma A, Nicaj L. Lead poisoning among pregnant women in New York City: Risk factors and screening practices. J Urban Health. 2012;79(2):225237.

22.Jong WC, Soon KK. Relationships of lead, copper, zinc, and cadmium levels versus hematopoiesis and iron parameters in healthy adolescents. Ann Clin Lab Sci. 2005;35(4):428-434.

23. Froom $P$, Kristal-Bonch E, Benbassat J. Lead exposure in battery -factory workers is not associated with anemia. J Occup Environ Med. 199;41:120-123.

24. Counter SA, Buchanan LH, Ortega F, et al. Blood lead and hemoglobin levels in Andean children with chronic lead intoxication. Neurotoxicology. 2000;21:301-308.

25. Tripathi RM, Raghunath R, Mahapatra S, et al. Blood lead and its effect on $\mathrm{Cd}, \mathrm{Cu}, \mathrm{Zn}, \mathrm{Fe}$ and hemoglobin levels of children. Sci Total Environ. 2001;277(1-3):161-168.

26. Zogai D, Krasniqi S, Elezaj I, et al. Correlation between blood lead level and hemoglobin level in Mitrovica children. Med Arch. 2014;68(5):324-328.

27. Mahmoud A, Amin Nada S, Hasan M. Maternal blood lead, sociodemographic and clinical risk factors of unfavourable pregnancy outcomes: A case control study among pregnant women in Egypt. J Appl Sci Res. 2012;8(12):5829-5845.

28. Sim P, Lee H, Kim Y. Effects of iron therapy on blood lead concentrations in infants. J Trace Elem Med Biol. 2014;28(1):56-9.

29. Sim P, Kim Y, Lee H, et al. Iron deficiency increases blood lead levels in boys and pre-menarche girls surveyed in KNHANES 2010-2011. Environ Res. 2014;130:1-6.

30. Wright RO, Tsaih SW, Schwartz J, et al. Association between iron deficiency and blood lead level in a longitudinal analysis of children followed in an urban primary care clinic. J Pediatr. 2003;142:9-14.

31. Wolf AW, Jimenez E, Lozoff B. Effects of iron therapy on infant blood lead levels. J Pediatr. 2003;143:789-795.

32. Kim Y, Lobdell DT, Wright CW, et al. Blood metal concentrations of manganese, lead, and cadmium in relation to serum ferritin levels in Ohio residents. Biol Trace Elem Res. 2015;165:1-9.

33. Rosado JL, Lopez $\mathrm{P}$, Kordas $\mathrm{K}$, et al. Iron and/or zinc supplementation did not reduce blood lead 
concentrations in children in a randomized, placebocontrolled trial. J Nutr. 2006;136:2378-2383.

34. Bárány $E$, Bergdahl IA, Bratteby LE, et al. Iron status influences trace element levels in human blood and serum. Environ Res. 2005;98(2):215-23.

35. Serwint JR, Damokosh Al, Berger OG, et al. No difference in iron status between children with low and moderate lead exposure. J Pediatr. 1999;135:108-110.

36. Hammad TA, Sexton M, Langenberg P. Relationship between blood lead and dietary iron intake in preschool children: a cross-sectional study. Ann Epidemiol. 1996;6(1):30-3.

37. Park JH, Park S, Kim Y. Iron deficiency is not associated with increased blood cadmium in infants. Ann Occup Environ Med. 2014;26:3.

38. Choi JW, Kim SK. Association between blood lead concentrations and body iron status in children. Arch Dis Child. 2003;88:791-792.

39. Choi JW, Kim SK. Relationships of lead, copper, zinc, and cadmium levels versus hematopoiesis and iron parameters in healthy adolescents. Ann Clin Lab Sci. 2005;35:428-434.

40. Barany E, Bergdahl IA, Bratteby LE, et al. Iron status influences trace element levels in human blood and serum. Environ Res. 2005;98:215-223.

\section{ACKNOWLEDGEMENTS}

The authors are grateful to King Abdullah University Hospital, Princess Haya Biotechnology Center and Jordan University of Science and Technology for support conducting this study.

\section{PEER REVIEW}

Not commissioned. Externally peer reviewed.

\section{CONFLICTS OF INTEREST}

The authors declare that they have no competing interests.

\section{FUNDING}

This study was funded by Jordan University of Science and Technology.

\section{ETHICS COMMITTEE APPROVAL}

The IRB approval of this research was sought by the Ethics Committee of Jordan University of Science and Technology [GM760]. The research protocol was approved by the institutional Ethics Committee (IRB) of the King Abdulla University Hospital (KAUH) at Jordan University of Science and Technology. All women signed an informed consent form agreeing to participate in this study. All participants were assured that the data they provide will not be traced back to them in reports, presentations and other forms of dissemination. The use of pseudonyms names ensured that none of the participants would be identifiable and remain anonymous. 
Table 1: The socio-demographic and relevant characteristics of the participants

\begin{tabular}{|l|l|l|}
\hline Age & $\mathbf{n}$ & \% \\
\hline$<30$ & 92 & 55.8 \\
\hline$\geq 30$ & 73 & 44.2 \\
\hline Education & & \\
\hline$<$ bachelor degree & 68 & 42.2 \\
\hline$\geq$ bachelor degree & 93 & 57.8 \\
\hline Income (JDs; 1 JD = 1.04 US \$) & & \\
\hline$<600$ & 101 & 60.8 \\
\hline$\geq 600$ & 65 & 39.2 \\
\hline Parity & & \\
\hline Primiparous & 37 & 22.4 \\
\hline $02-$ Mar & 87 & 52.7 \\
\hline$>3$ & 41 & 24.8 \\
\hline Trimester & & \\
\hline First & 17 & 10.2 \\
\hline Second & 19 & 11.4 \\
\hline Third & 131 & 78.4 \\
\hline Iron intake/Day & 87 & 52.4 \\
\hline Multivitamins Intake & 68 & 41 \\
\hline
\end{tabular}

Table 2: The means of haemoglobin, lead, and iron according to the studied characteristics

\begin{tabular}{|c|c|c|c|c|c|c|c|c|c|}
\hline & \multirow{2}{*}{\multicolumn{2}{|c|}{$\begin{array}{l}\text { Haemoglobin level } \\
\text { (g/dl) }\end{array}$}} & \multirow[b]{3}{*}{$P$ value } & \multirow{2}{*}{\multicolumn{2}{|c|}{ Lead level ( $\mu \mathrm{g} / \mathrm{dL})$}} & \multirow[b]{3}{*}{$P$ value } & \multirow{2}{*}{\multicolumn{2}{|c|}{$\begin{array}{l}\text { Iron level } \\
\text { (mg/L) }\end{array}$}} & \multirow[b]{3}{*}{$P$ value } \\
\hline & & & & & & & & & \\
\hline & Mean & SD & & Mean & SD & & Mean & SD & \\
\hline Age & & & 0.271 & & & 0.602 & & & 0.618 \\
\hline$<30$ & 10.8 & 1.7 & & 12.1 & 3.3 & & 2.3 & 2.7 & \\
\hline$\geq 30$ & 10.5 & 1.5 & & 12.4 & 4.1 & & 2.1 & 2.6 & \\
\hline Education & & & 0.899 & & & 0.667 & & & 0.793 \\
\hline$<$ bachelor & 10.6 & 1.6 & & 12.4 & 3.9 & & 2.1 & 2.5 & \\
\hline$\geq$ bachelor & 10.6 & 1.6 & & 12.1 & 3.5 & & 2.3 & 2.8 & \\
\hline Income & & & 0.020 & & & 0.048 & & & 0.889 \\
\hline$<600$ & $10.9 *$ & 1.7 & & $11.8^{*}$ & 3.5 & & 2.3 & 2.8 & \\
\hline$\geq 600$ & 10.3 & 1.4 & & 12.9 & 3.7 & & 2.2 & 2.4 & \\
\hline Parity & & & 0.508 & & & 0.246 & & & 0.867 \\
\hline Primiparous & 10.9 & 1.8 & & 12 & 3 & & 2.4 & 1.4 & \\
\hline$\leq 3$ & 10.6 & 1.6 & & 12.6 & 3.9 & & 2.1 & 2.8 & \\
\hline$>3$ & 10.5 & 1.6 & & 11.6 & 3.5 & & 2.4 & 3.1 & \\
\hline Trimester & & & $<0.005$ & & & 0.04 & & & 0.316 \\
\hline First & $12.2^{*}$ & 2.1 & & $10.3^{*}$ & 1.9 & & 2.1 & 1.4 & \\
\hline Second & 11.4 & 2 & & 11.6 & 2.6 & & 1.4 & 0.7 & \\
\hline Third & 10.3 & 1.3 & & 12.5 & 3.8 & & 2.4 & 3 & \\
\hline Multivitamins & & & 0.041 & & & 0.048 & & & 0.441 \\
\hline NO & $10.9 *$ & 1.7 & & $11.7^{*}$ & 3.4 & & 2.4 & 3 & \\
\hline YES & 10.3 & 1.4 & & 12.9 & 3.8 & & 2 & 2 & \\
\hline
\end{tabular}


Table 3: The differences in the means of haemoglobin and iron between low and high levels of lead

\begin{tabular}{|l|c|c|c|c|c|}
\hline \multirow{2}{*}{} & \multicolumn{4}{|c|}{ Lead $(\mu \mathrm{g} / \mathrm{dL})$} & \\
\cline { 2 - 6 } & \multicolumn{2}{|c|}{$<10$} & \multicolumn{2}{c|}{$\geq 10$} & \\
\hline & Mean & SD & Mean & SD & P-value * \\
\hline $\begin{array}{l}\text { Haemoglobin } \\
\text { level (g/dl) }\end{array}$ & 10.9 & 1.7 & 10.5 & 1.6 & 0.149 \\
\hline $\begin{array}{l}\text { Iron level } \\
\text { (mg/L) }\end{array}$ & 2.4 & 3.3 & 2.2 & 2.2 & 0.624 \\
\hline *Independent t test & & & & \\
\hline
\end{tabular}

Table 4: Multiple linear regression of the association between lead and other parameters including haemoglobin and Iron

\begin{tabular}{|c|c|c|c|c|c|c|}
\hline $\begin{array}{l}\text { Dependent } \\
\text { Variable } \\
\mathrm{Hb} \\
\end{array}$ & $\begin{array}{l}\text { Independent } \\
\text { variables }\end{array}$ & $\begin{array}{c}\text { Coefficient } \\
\text { (B) }\end{array}$ & SE (B) & \multicolumn{2}{|c|}{$95 \%$ confidence interval } & \multirow[t]{2}{*}{ P-value } \\
\hline & & & & & & \\
\hline & Age in years & 0 & 0.02 & -0.05 & 0.05 & 0.897 \\
\hline & Education & 0.15 & 0.23 & -0.31 & 0.62 & 0.516 \\
\hline & Income & -0.43 & 0.25 & -0.92 & 0.06 & 0.082 \\
\hline & Parity & -0.07 & 0.19 & -0.45 & 0.31 & 0.712 \\
\hline & Gestational age & -0.36 & 0.06 & -0.48 & -0.25 & $<0.005$ \\
\hline & Iron intake & -0.08 & 0.28 & -0.63 & 0.47 & 0.767 \\
\hline & $\begin{array}{l}\text { Multivitamins } \\
\text { use }\end{array}$ & -0.42 & 0.24 & -0.9 & 0.06 & 0.083 \\
\hline & Lead & 0.04 & 0.03 & -0.02 & 0.1 & 0.223 \\
\hline \multicolumn{7}{|l|}{ Iron } \\
\hline & Age in years & -0.05 & 0.05 & -0.16 & 0.06 & 0.377 \\
\hline & Education & 0.36 & 0.52 & -0.67 & 1.39 & 0.489 \\
\hline & Income & -0.17 & 0.56 & -1.27 & 0.93 & 0.76 \\
\hline & Parity & 0.23 & 0.43 & -0.62 & 1.09 & 0.588 \\
\hline & Gestational age & 0.16 & 0.13 & -0.09 & 0.42 & 0.209 \\
\hline & Iron intake & -0.58 & 0.62 & -1.8 & 0.64 & 0.346 \\
\hline & $\begin{array}{l}\text { Multivitamins } \\
\text { use }\end{array}$ & -0.9 & 0.54 & -1.98 & 0.17 & 0.100 \\
\hline & Lead & 0.13 & 0.08 & -0.03 & 0.29 & 0.116 \\
\hline
\end{tabular}

